\title{
TRIAS POLITICA DALAM PERSPEKTIF FIKIH SIYASAH
}

\author{
Wery Gusmansyah \\ Program Studi Hukum Tata Negara Fakultas Syariah IAIN Bengkulu \\ Jl. Raden Fatah Pagar Dewa Bengkulu \\ Email: wery_gusman2009@yahoo.com
}

\begin{abstract}
According to the concept of the trias politica Montesquieu, in every government there are three kinds of powers, namely the legislative power, the executive power, on matters pertaining to the law of nations; and judicial power on matters that depend on civil law ". According to him, these three types of power must be separate from each other, both about the task (function) and the equipment (organ) that organize it. Basically, the concept of trias politica does not conflict with the jurisprudence of siyasah. The implementation of this power-sharing can be seen in the time of the khulafaurrasyidin. At that time the executive power held by a caliph, the legislative power held by the Council of Shura, and the power of the judiciary held by Qadhi or judge. Then, during the second caliphate of Umar bin Khattab, the division of power between the executive, the legislative, and the judiciary was elaborated by law. At this time, Umar bin Khattab made a law that separates the executive and legislative powers, with the aim that the qadhi as the holder of the judicial power in deciding cases can be free from executive influence.
\end{abstract}

Keywords: trias politica, fiqh siyasah, the benefit of the ummah

\begin{abstract}
Abstrak: Menurut konsep trias politica Montesquieu, dalam tiap pemerintahan ada tiga macam kekuasaan, yaitu kekuasaan legislatif, kekuasaan eksekutif, mengenai hal-hal yang berkenaan dengan hukum antarbangsa; dan kekuasaan yudikatif mengenai hal-hal yang bergantung pada hukum sipil”. Menurutnya, ketiga jenis kekuasaan ini haruslah terpisah satu sama lain, baik mengenai tugas (fungsi) maupun mengenai alat perlengkapan (organ) yang menyelenggarakannya. Pada dasarnya, konsep trias politica tidak bertentangan dengan fikih siyasah. Implementasi pembagian kekuasaan ini dapat dilihat pada masa khulafaurrasyidin. Saat itu kekuasaan eksekutif dipegang oleh seorang khalifah, kekuasaan legeslatif dipegang oleh Majelis Syura, dan kekuasaan yudikatif dipegang oleh Qadhi atau hakim. Kemudian, pada masa khilafah kedua yaitu Umar bin Khattab, pembagian kekuasaan antara eksekutif, legeslatif, dan yudikatif dirinci lewat undang-undang. Pada masa ini juga, Umar bin Khattab membuat undang-undang yang memisahkan antara kekuasaan eksekutif dan legeslatif, dengan tujuan agar para qadhi sebagai pemegang kekuasaan yudikatif dalam memutuskan perkara bisa bebas dari pengaruh eksekutif.
\end{abstract}

Kata kunci: trias politica, fikih siyasah, kemaslahatan umat 


\section{Pendahuluan}

Salah satu dari beberapa indikasi sebuah negara dikategorikan negara hukum dalam pandangan Julius Sthal adalah adanya pembagian atau pemisahan kekuasaan. Pemisahan kekuasaan atau yang dikenal dengan istilah trias politica merupakan konsep pemerintahan yang kini banyak dianut di berbagai negara di belahan dunia. Trias politica adalah anggapan bahwa kekuasaan negara terdiri atas tiga macam kekuasaan: Pertama, kekuasaan legislatif atau kekuasaan membuat undang-undang (rule making function); kedua, kekuasaan eksekutif atau kekuasaan melaksanakan undang-undang (rule application function); ketiga kekuasaan yudikatif atau kekuasaan mengadili atas pelanggaran undang-undang (rule adjudication function). Trias politica adalah suatu prinsip normatif bahwa kekuasaan-kekuasaan (function) ini sebaiknya tidak diserahkan kepada orang yang sama untuk mencegah penyalahgunaan kekuasaan oleh pihak yang berkuasa. Dengan demikian hak-hak asasi warga negara lebih terjamin. ${ }^{1}$

Menurut sejarah fungsi-fungsi kekuasaan negara ini pertama kali di kenal diPerancis pada abad ke-XVI, yang pada umumnya diakui lima yaitu: fungsi diplomacie, fungsi defencie, fungsi financie, fungsi justicie, dan fungsi policie. ${ }^{2}$ Kemudian John Locke (1632-1711)dalam bukunyaTwo Treatises on Civil Goverment (1960)membagi fungsi kekuasaan negara itu menjadi tiga fungsi, yaitu; fungsi legislatif, fungsi eksekutif,dan fungsi federatif (hubungan luar negeri), yang masing-masing terpisah satu sama lain. Bagi John Locke, fungsi peradilan tercakup dalam fungsi eksekutif atau pemerintahan. John Locke memandang mengadili itu sebagai uittvoering, yaitu termasuk pelaksanaan undang-undang. ${ }^{3}$

Sehubungan dengan konsep trias politica, Montesquieu menulis dalam bukunya yang berjudul The Sprit of Law (1748) sebagai berikut: "dalam tiap pemerintahan ada tiga macam kekuasaan,

\footnotetext{
${ }^{1}$ Miriam Budiardjo, Dasar-Dasar Ilmu Politik. Edisi Revisi, (Jakarta: Pertama, Gramedia, 2008), h. 281-282.

2 Jimly Asshiddiqie, Perkembangan dan Konsulidasi Lembaga Negara Pasca Reformasi. (Jakarta: Sinar Grafika, 2010), h. 29.

${ }^{3}$ Miriam Budiardjo, Dasar-Dasar Ilmu..., h. 282
}

yaitu kekuasaan legislatif, kekuasaan eksekutif, mengenai hal-hal yang berkenaan dengan hukum antarbangsa; dan kekuasaan yudikatif mengenai hal-hal yang bergantung pada hukum sipil”. ${ }^{4}$ Menurutnya ketiga jenis kekuasaan ini haruslah terpisah satu sama lain, baik mengenai tugas (fungsi) maupun mengenai alat perlengkapan (organ) yang menyelenggarakannya. Terutama adanya kebebasan badan yudikatif yang ditekankan oleh Montesquieu yang mempunyai latar belakang sebagai hakim, karena disinilah letaknya kemerdekaan individu dan hak asasi manusia perlu dijamin dan dipertaruhkan. Kekuasaan legislatif menurutnya adalah kekuasaan untuk membuat undang-undang, kekuasaan eksekutif meliputi penyelenggaraan undangundang (diutamakan tindakan politik luar negeri), sedangkan kekuasaan yudikatif adalah kekuasaan mengadili atas pelanggaran undang-undang.

Lebih lanjut Montesquieu mengemukakan bahwa kemerdekaan hanya dapat dijamin jika ketiga fungsi kekuasaan negara itu tidak dipegang oleh satu orang atau badan tetapi oleh ketiga orang atau badan yang terpisah. Dikatakan olehnya "kalau kekuasaan legislatif dan kekuasaan eksekutif disatukan dalam satu orang atau dalam satu badan penguasa, maka tak akan ada kemerdekaan, akan menjadi malapetaka jika seandainya satu orang atau satu badan yang memegang kekuasaan itu. Yakni kekuasaan membuat undang-undang, menyelenggarakan keputusan-keputusan umum, dan mengadili persoalan-persoalan antara individuindividu, ”

Melaksanakan teori Trias Politica secara murni seperti yang dimaksudkanoleh Montesquieu adalah tidak mungkin, karena praktek ketatanegaraan akhir-akhir ini menunjukkan bahwa pembuat undang-undang yang seharusnya merupakan tugas legislatif saja, pada kenyataannya eksekutif juga diikutsertakan. Menurut E. Utrecht, pemisahan mutlak yang dikemukakan oleh Montesquieu mengakibatkan adanya badan negara yang tidak ditempatkan dibawah pengawasan badan kenegaraan lainnya. Ketiadaan pengawasan ini mengakibatkan terbukanya kemungkinan

\footnotetext{
${ }^{4}$ Miriam Budiardjo, Dasar-Dasar Ilmu..., h. 283
} 
suatu badan kenegaraan melampaui batas kekuasaannya. Jika dilihat dari fungsi negara pada negara hukummodern, pembagian tiga fungsi kekuasaan negara tidak dapat diterima secara mutlak, karena suatu badan negara juga dapat diberi lebih dari satu fungsi. ${ }^{5}$

Seperti halnya dalam sistem ketatanegaraan negara Republik Indonesia, seperti yang tercantum dalam Undang-Undang Dasar Negara Republik Indonesia Tahun 1945, tidak menganut suatu sistem pemisahan kekuasaan manapun, tetapi adalah suatu sistem ketatanegaraan khas menurut kepribadian negara Indonesia.

Namun, sistem ketatanegaraan Republik Indonesia tidak terlepas dari ajaran Trias Politica. Karena, ajaran trias politica tersebut adalah ajaran tentang pemisahan kekuasaan negara menjadi tiga yaitu Legislatif, Eksekutif, dan Yudikatif yang kemudian masing-masing kekuasaan tersebut dalam pelaksanaannya diserahkan kepada satu badan mandiri, artinya masing-masing badan itu satu sama lain tidak dapat saling mempengaruhi dan tidak dapat saling meminta pertanggung jawaban. Sedangkan dalam sistem ketatanegaraan Indonesia, pemisahan kekuasaan itu disertai dengan prinsip hubungan saling mengawasi dan mengimbangi (check and balance) antara lembaga negara ${ }^{6}$.

Sistem Check and Balance tersebut dimaksud agar ketiga badan (Legislatif, Eksekutif, dan Yudikatif) itu tidak menjalankan kekuasaannya melebihi atau kurang dari masing-masing kekuasaan yang ditentukan oleh konstitusi. Dalam negara Indonesia kekuasaan legeslatif dipegang oleh lembaga DPR dan DPD, Kekuasaan eksekutif dipegang oleh Presiden dan Kekuasaan yudikatif dipegang olehMahkamah Agung dan Badan peradilan dibawahnya dan oleh sebuah Mahkamah Konstitusi.

Berkaitan dengan teori trias politica ini, hukum Islam pun mengatur tentang hal tersebut. Dalam konsep hukum Islam, hal-hal yang berkaitan dengan pembagian kekuasaan di bahas dalam kajian siyasah

${ }^{5}$ E.Utrech, Pengantar Hukum Administrasiu Negara Indonesia, Cet. 4, 1960, h. 17-24

${ }^{6}$ Moh. Kusnardi dan R. Saragih, Susunan Pembagian Kekuasaan Menurut Sistem Undang-Undang Dasar 1945,(Jakarta: PT Gramedia Pustaka Utama, 1994), h. 32. dusturiyah. Dalam siyasah dusturiyah, kekuasaan itu dikenal dengan istilah "Majlis Syura" atau "ahl al-halli wa al-aqdi" atau seperti yang disebut Abu A'la al-Maududi sebagai "Dewan Penasehat"' serta al-Mawardi menyebutnya dengan ahl al-Ikhtiyar. ${ }^{8}$

Pemikiran politik Islam merupakan hasil kajian filosofis ke dalam bentuk dan peranan pemerintahan yang berkaitan dengan persoalanpersoalan agama dan dunia, dan dalam hubungannya dengan perubahan sosial didunia Islam. Dasardasar politik Islam tergambar dalam firman Allah SWT yang artinya sebagai berikut:

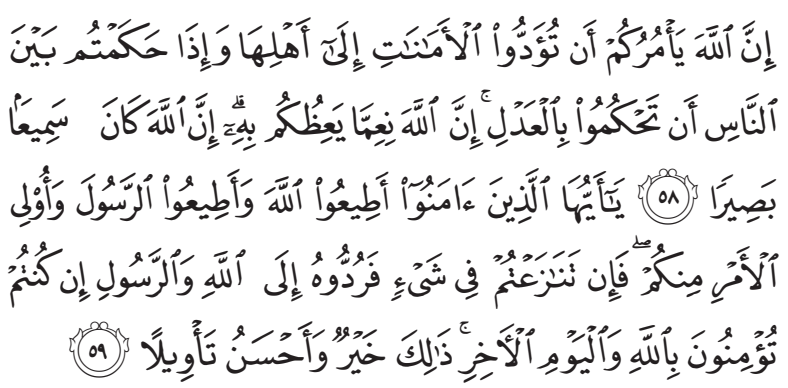
"Sesungguhnya Allah menyuruh kamu menyampaikan amanat kepada yang berhak menerimanya, dan (menyuruh kamu) apabila menetapkan hukum di antara manusia supaya kamu menetapkan dengan adil. Sesungguhnya Allah memberi pengajaran yang sebaik-baiknya kepadamu. Sesungguhnya Allah adalah Maha mendengar lagi Maha melihat. 59. Hai orang-orang yang beriman, taatilah Allah dan taatilah Rasul (Nya), dan ulil amri di antara kamu. kemudian jika kamu berlainan Pendapat tentang sesuatu, Maka kembalikanlah ia kepada Allah (Al Quran) dan Rasul (sunnahnya), jika kamu benarbenar beriman kepada Allah dan hari kemudian. yang demikian itu lebih utama (bagimu) dan lebih baik akibatnya." (QS. Al-Nisa’:58-59)

Kekuasaan (sultah) dalam negara Islam, Abdul Wahab Khallaf membaginya menjadi tiga bagian, yaitu: ${ }^{9}$

1. Lembaga legislatif (sultah tasyri'iyah), lembaga ini adalah lembaga negara yang menjalankan kekuasaan untuk membuat undang-undang.

\footnotetext{
${ }^{7}$ A. Djazuli, Fiqh Siyasah, Implementasi Kemaslahatan Umat dalam Rambu-Rambu Syari'ah, h.76

${ }^{8}$ Munawir Sjadzali, Islam dan Tata Negara, Ajaran, Sejarah dan Pemikiran,h. 64

${ }^{9}$ Ahmad Sukarjo, Ensiklopedi Tematis Dunia Islam, h. 197
} 
2. Lembaga eksekutif (sultah tanfiziyyah), lembaga ini adalah lembaga negara yang berfungsi menjalankan undang-undang.

3. Lembaga yudikatif (sultah Qada'iyyah), lembaga ini adalah lembaga negarayang menjalankan kekuasaan kehakiman.

Implementasi pembagian kekuasaan ini dapat kita lihat pada masa khulafaur rasyidin. Pada masa itu kekuasaan Eksekutif dipegang oleh seorang khalifah, kekuasaan legeslatif dipegang oleh Majelis Syuro, dan kekuasaan Yudikatif dipegang oleh Qadhi atau hakim. Kemudian, pada masa khilafah kedua yaitu Umar Bin Khattab pembagian kekuasaan antara Eksekutif, Legeslatif, dan Yudikatif diperinci lewat undang-undang. Pada masa ini juga, Umar bin Khattab membuat undang-undang yang memisahkan antara kekuasaan eksekutif dan legeslatif, dengan tujuan para qadhi sebagai pemegang kekuasaan yudikatif dalam memutuskan perkara harus bebas dari pengaruh eksekutif.

\section{Implementasi Konsep Trias Politica}

Trias Politica adalah anggapan bahwa kekuasaan negara terdiri atas tiga macam kekuasaan: Pertama, kekuasaan legislatif atau kekuasaan membuat undang-undang (rule making function); kedua, kekuasaan eksekutif atau kekuasaan melaksanakan undang-undang (rule application function); ketiga kekuasaan yudikatif atau kekuasaan mengadili atas pelanggaran undang-undang (rule adjudication function). Trias politica adalah suatu prinsip normatif bahwa kekuasaan-kekuasaan (function) ini sebaiknya tidak diserahkan kepada orang yang sama untuk mencegah penyalahgunaan kekuasaan oleh pihak yang berkuasa. Dengan demikian, hak-hak asasi warga negara lebih terjamin. ${ }^{10}$

Konsep dasar dari trias politica ini adalah kekuasaan di suatu negara tidak boleh dilimpahkan pada satu struktur kekuasaan politik melainkan harus terpisah di lembaga-lembaga negara yang berbeda. Lembaga-lembaga negara tersebut adalah lembaga-lembaga pemerintah yang memiliki kewenangan untuk mewujudkan dan melaksanakan

${ }^{10}$ Miriam Budiardjo, Dasar-Dasar Ilmu Politik. Edisi Revisi,Cetakan Pertama, Gramedia, Jakarta, 2008, h. 281-282. kewenangan eksekutif, lembaga-lembaga pengadilan yang berwenang menyelenggarakan kekuasaan yudikatif dan lembaga-lembaga perwakilan rakyat yang memiliki kewenangan menjalankan kekuasaan legislatif. Di bawah sistem ini, keputusan legislatif dibuat oleh masyarakat atau oleh wakil rakyat yang wajib bekerja dan bertindak sesuai aspirasi masyarakat yang diwakilinya (konstituen) dan yang memilihnya melalui proses pemilihan umum legislatif, selain sesuai hukum dan peraturan. Dengan adanya pemisahan kekuasaan ini, akan terjamin kebebasan pembuatan undang-undang oleh parlemen, pelaksanaan undang-undang oleh lembaga peradilan, dan pelaksanaan pekerjaan negara sehari-hari oleh pemerintah.

\section{a. Badan Legislatif}

Badan legislatif atau Legislaturre mencerminkan salah satu fungsi badan itu, yaitu legislate, atau membuat undang-undang. Nama lain yang sering dipakai ialah Assembly yang mengutamakan unsur "berkumpul” (untuk membicarakan masalahmasalah publik). Nama lain lagi adalah Parliament, suatu istilah yang menekankan unsur "bicara" dan merundingkan. Sebutan lain mengutamakan representasi atau keterwakilan anggota-anggotanya dalam dinamika People's representative body atau dewan perwakilan rakyat. Akan tetapi apa pun perbedaan dalam namanya dapat di pastikan bahwa badan ini merupakan simbol dari rakyat yang berdaulat. ${ }^{11}$

Menurut trias politica, fungsi dari kekuasaan legislatif sebagai berikut ${ }^{12}$ :

a. Lawmaking ( legislasi )

b. Fungsi Anggaran

c. Fungsi Constituency Work

d. Fungsi Supervision and Criticism Government

e. Fungsi Education

f. Fungsi Perwakilan (Representation)

Dianutnya ketiga sistem perwakilan ini menentukan bentuk dan struktur pelembagaan sistem perwakilan itu di setiap negara. Pilihan sistem

${ }^{11}$ Rohaniah Yoyoh, Efriza, Pengantar Ilmu Politik Kajian Mendasar Ilmu Politik, Malang, Intrans Publising 2005. Hal 292

${ }^{12}$ Muhammad Iqbal, 2011, Sejarah Terbentuknya DPR, Jakarta, Darma Pustaka, hlm 13. 
perwakilan itu selalu tercermin dalam struktur kelembagaan parlemen yang dianut suatu negara. Pada umumnya, di setiap negara dianut salah satu atau paling banyak dua dari ketiga sistem tersebut secara bersamaan. Dalam hal negara yang bersangkutan menganut salah satu dari ketiganya, pelembagaannya tercermin dalam stuktur parlemen saatu kamar. Artinya, struktur lembaga perwakilan rakyat yang dipraktikan oleh negara itu mestilah parlemen satu kamar (unicemeral parliament). Jika sistem yang dianut itu mencakup dua fungsi, kedua fungsi itu selalu dilembagakan dalam struktur parlemen dua kamar (bicameral parliament).

\section{b. Lembaga Eksekutif}

Kekuasaan eksekutif biasanya dipegang oleh lembaga eksekutif. Di negara-negara demokratis, lembaga eksekutif biasanya terdiri atas kepala negara seperti raja atau presiden, beserta menterimenterinya. Lembaga eksekutif dalam arti luas juga mencakup para pegawai negeri sipil dan militer. ${ }^{13}$

Lembaga eksekutif adalah suatu lembaga eksekutor atau melaksanakan undang-undang. Dalam kehidupan sehari-hari, lembaga eksekutif adalah lembaga yang menjalankan roda pemerintahan. Di negara-negara demokratis, lembaga eksekutif biasanya terdiri dari kepala negara seperti raja/presiden, beserta menteri-menterinya. ${ }^{14}$

Dengan sistem presidensial menteri-menteri merupakan pembantu presiden dan langsung di pimpin olehnya, sedangkan dalam sistem parlementer para menteri dipimpin oleh seorang perdana menteri. Dalam sistem parlementer pula perdana menteri beserta menteri-menterinya dinamakan bagian dari badan eksekutif yang bertanggung jawab, sedangkan raja dalam monarki konstitusional dinamakan "bagian dari badan eksekutif yang tidak dapat diganggu gugat (the king can do no wrong)". ${ }^{15}$

Menurut tafsiran tradisional azas Trias Politica, tugas lembaga eksekutif adalah melaksanakan kebijaksanaan-kebijaksanaan yang telah ditetapkan oleh lembaga legislatif, serta menyelenggarakan

\footnotetext{
${ }^{13}$ Rohaniah Yoyoh, Efriza, Pengantar Ilmu Politik...., h 293

${ }^{14}$ Jimly Asshiddiqie, Pengantar Ilmu..., h 323

${ }^{15}$ Rohaniah Yoyoh, Efriza, Pengantar Ilmu Politik...., h 293
}

undang-undang yang dibuat oleh lembaga legislatif. Namun dalam pelaksanaannya, lembaga eksekutif sangat luas ruang geraknya. Zaman modern telah menimbulkan paradoks bahwa wewenang lembaga eksekutif dewasa ini jauh lebih luas daripada hanya melaksanakan undang-undang saja. ${ }^{16}$ Ramsey menyatakan bahwa dalam negara modern, lembaga eksekutif sudah menggantikan posisi lembaga legislatif sebagai pembuat kebijaksanaan yang utama. ${ }^{17}$ Fungsifungsi kekuasaan eksekutif ini garis besarnya adalah :18

1) Kepala Negara (Chief Of State)

2) Kepala Pemerintahan (Head of Government)

3) Party Chief

4) Commander in Chief

5) Chief Diplomat

6) Dispensen Appointment

7) Chief Legislation

\section{c. LembagaYudikatif}

Lembaga yudikatif merupakan suatu badan yang memiliki sifat teknis-yuridis yang berfungsi mengadili penyelewengan pelaksanaan konstitusi dan peraturan perundang-undangan oleh institusi pemerintahan secara luas serta bersifat independen (bebas dari intervensi pemerintah) dalam pelaksanaan tugas dan fungsinya. ${ }^{19}$

Kekuasaan kehakiman merupakan pilar ketiga dalam sistem kekuaaan negara modern. Dalam bahasa Indonesia, fungsi kekuasaan ketiga ini sering kali disebut cabang kekuasaan "yuikatif", dari istilah belanda judicatief. Dalam bahasa Inggris, disamping istilah legeslative, executive, tidak dikenal istilah judikative sehingga untuk pengertian yang sama biasanya dipakai istilah judicial, judiciary, ataupun judicature. ${ }^{20}$

Kekuasaan kehakiman ini berwenang menafsirkan isi undang-undang maupun memberi sanksi atas setiap pelanggaran atasnya. Fungsifungsi Yudikatif yang bisa dispesifikasikan kedalam daftar masalah hukum berikut: Criminal law (petty offense, misdemeanor, felonies); Civil law

\footnotetext{
${ }^{16}$ Rohaniah Yoyoh, Efriza, Pengantar Ilmu Politik...., h294

${ }^{17}$ Miriam Budiardjo, Dasar-Dasar ilmu...., h 209

${ }^{18}$ Ibid.,h 210

${ }^{19}$ Rohaniah Yoyoh, Efriza, Pengantar Ilmu Politik...., h 295

${ }^{20}$ Jimly Asshiddiqie, Pengantar Ilmu..., h 310
} 
(perkawinan, perceraian, warisan, perawatan anak); Constitution law (masalah seputar penafsiran kontitusi); Administrative law (hukum yang mengatur administrasi negara); International law (perjanjian internasional).

\section{1) Criminal Law \\ 2) Constitution Law. \\ 3) Administrative Law \\ 4) International Law}

\section{Trias Politica dalam Perspektif Siyasah}

Islam merupakan agama yang komprehensif dan telah mengatur seluruh sendi kehidupan manusia, tidak hanya dalam masalah individual namun termasuk juga dalam masalah kenegaraan. Berkaitan dengan sistem pemerintahan, dalam Islam tercermin sebagaimana pada konsep imamah dimana hal ini secara eksplisit telah diatur dalam siyasah dusturiyah, yaitu siyasah yang berhubungan dengan peraturan dasar tentang bentuk pemerintahan dan batasan kekuasaannya, cara pemilihan (kepala negara), batasan kekuasaan yang lazim bagi pelaksanaan urusan umat, dan ketetapan hak-hak yang wajib bagi individu dan masyarakat, serta hubungan antara penguasa dan rakyat.

Ruang lingkup pembahasan dalam siyasah dusturiyah ini meliputi masalah-masalah imamah, hak dan kewajibannya, rakyat status dan hakhaknya, bai'at, waliyul 'ahdi, perwakilan, 'ahlul halli wal aqdi dan wazarah. ${ }^{21}$

Siyasah dusturiyah adalah bagian dari Fiqh Siyasah yang membahas masalah perundangundangan Negara agar sejalan dengan nilai-nilai syari'at. Artinya, undang-undang itu mengacu terhadap konstitusinya yang tercermin dalam prinsip-prinsip Islam dalam hukum-hukum syari'at yang disebutkan di dalam Alquran dan yang dijelaskan sunnah Nabi, baik mengenai akidah, ibadah, akhlak, muamalah maupun berbagai macam hubungan yang lain. ${ }^{22}$

Prinsip-prinsip yang diletakkan dalam pe-

${ }^{21}$ Suyuthi Pulungan, Fiqh Siyasah, (Jakarta: Raja Grafindo Persada, 1994), h 40-41

${ }^{22}$ Yusuf al-Qardhawi, Fikih Daulah dalam Perspektif al-Qur'an dan Sunnah Alih Bahasa Kathun Suhadi, h. 46-47 rumusan undang-undang dasaradalah jaminan atas hak asasi manusia setiap anggota masyarakat dan persamaan kedudukan semua orang di mata hukum, tanpa membeda-bedakan stratifikasisosial, kekayaan, pendidikan dan agama. ${ }^{23}$ Sehingga tujuan dibuatnya peraturanperundang-undangan untuk merealisasikan kemaslahatan manusia dan untukmemenuhi kebutuhan manusia yang merupakan prinsip Fiqh Siyasah akantercapai. ${ }^{24}$

Sebagai suatu petunjuk bagi manusia, Alquran menyediakan suatu dasaryang kukuh dan tidak berubah bagi semua prinsip-prinsip etik dan moral yangperlu bagi kehidupan ini. Menurut Muhammad Asad, Alquran memberikansuatu jawaban komprehensif untuk persoalan tingkah laku yang baik bagi manusia sebagai anggota masyarakat dalam rangka menciptakan suatukehidupan berimbang di dunia ini dengan tujuan terakhir kebahagiaan diakhirat. ${ }^{25}$ Ini berarti penerapan nilainilai universal Alquran dan hadist adalahfaktor penentu keselamatan umat manusia di bumi sampai di akhirat, sepertiperaturan yang pernah diperaktekkan Rasulullah saw dalam negara Islam pertama yang disebut dengan "Konstitusi Madinah" atau "Piagam Madinah". ${ }^{26}$

Isi penting dari prinsip Piagam Madinah adalah membentuk suatumasyarakat yang harmonis, mengatur sebuah umat dan menegakkan pemerintahan atas dasar persamaan hak. ${ }^{27}$ Piagam Madinah ini juga merupakan suatu konstitusi yang telah meletakkan dasar-dasar sosial politik bagimasyarakat Madinah dalam sebuah pemerintahan dibawah kepemimpinan Nabi Muhammad. Piagam Madinah dianggap oleh para pakar politik sebagai Undang-Undang Dasar pertama dalam negara Islam yang didirikan oleh NabiMuhammad.28

Setelah Nabi wafat, tidak ada konstitusi tertulis yang mengatur negaraIslam, umat Islam

${ }^{23}$ Muhammad Iqbal, Fiqh Siyasah, Kontekstualisasi Doktrin Politik Islam. h 154

${ }^{24}$ A. Djazuli, Fiqh Siyasah, Implementasi Kemaslahatan Umat dalam Rambu-Rambu Syari'ah, h 47

${ }^{25}$ Ahmad Syafi'i Ma’arif, Studi Tentang Peraturan dalam Konstitusi Islam dan Masalah Kenegaraan, h. 11

${ }^{26}$ Abdul Qodir Djailani, Negara Ideal Menurut Konsepsi Islam, h 119

${ }^{27}$ Munawir Sjadzali, Islam dan Tata Negara, Ajaran, Sejarah dan Pemikiran, h. 15-16

${ }^{28}$ Muhammad Iqbal, Fiqh Siyasah....., h. 157 
dari zaman ke zaman, dalam menjalankan roda pemerintahanberpedoman kepada prinsip-prinsip Alquran dan teladan Nabi dalamsunnahnya. Pada masa khalifah empat, teladan Nabi masih dapat diterapkandalam mengatur masyarakat Islam yang sudah berkembang. Namun pasca khulafa' ar-Rasidin tepatnya pada abad ke-19, setelah dunia Islam mengalami penjajahan barat, timbul pemikiran di kalangan ahli tata negara di berbagai dunia Islam untuk mengadakan konstitusi. Pemikiran ini timbul sebagai reaksi ataskemunduran umat Islam dan respon terhadap gagasan politik barat yang masukdi dunia Islam bersamaan dengan kolonialisme terhadap dunia Islam.

Sebab salah satu aspek dari isi konstitusi atau Undang-Undang Dasaradalah bidang-bidang kekuasaan negara. Kekuasaan itu dikenal dengan istilah"Majlis Syura” atau " ahl al-halli wa al-aqdi” atau seperti yang disebut Abu A'laal-Maududi sebagai "Dewan Penasehat" ${ }^{29}$ serta al-Mawardi menyebutnyadengan ahl al-Ikhtiyar. ${ }^{30}$

Di dalam sistem pemerintahan Islam juga terdapat pembagian kekuasaan seperti teori Trias Politica menurut fungsinya karena berdasarkan konstitusi Pemerintahan Islam dijelaskan pada surat An-Nisa ayat 58-59:

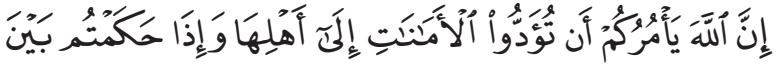

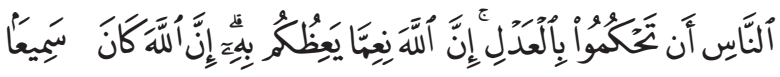

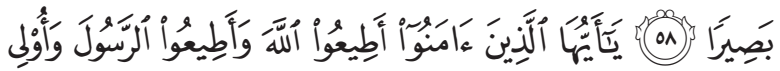

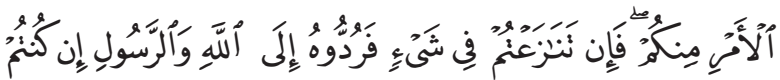

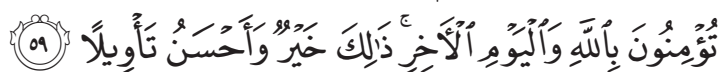
"Sesungguhnya Allah menyuruh kamu menyampaikan amanat kepada yang berhak menerimanya, dan (menyuruh kamu) apabila menetapkan hukum di antara manusia supaya kamu menetapkan dengan adil. Sesungguhnya Allah memberi pengajaran yang sebaik-baiknya kepadamu. Sesungguhnya Allah adalah Maha Mendengar lagi Maha Melihat. Hai orang-orang yang beriman, taatilah Allah dan taatilah Rasul (Nya), dan ulil amri di antara kamu. Kemudian jika kamu berlainan pendapat tentang

\footnotetext{
${ }^{29}$ A. Djazuli, Fiqh Siyasah......, h. 76

${ }^{30}$ Mudawir Sadzali, Islam dan Tata Negara......., h. 64
}

sesuatu, maka kembalikanlah ia kepada Allah (Al Quran) dan Rasul (sunnahnya), jika kamu benarbenar beriman kepada Allah dan hari kemudian. Yang demikian itu lebih utama (bagimu) dan lebih baik akibatnya."

Implementasi pembagian kekuasaan ini dapat kita lihat pada masa khulafaur rasyidin. Pada masa itu kekuasaan eksekutif dipegang oleh seorang khalifah, kekuasaan legislatif dipegang oleh Majelis Syuro' dan kekuasaan yudikatif dipegang oleh Qadhi atau hakim. Pada masa Khulafaur Rasyidin, khalifah (eksekutif) pertama dalam negara Islam adalah Abu Bakar. Sedangkan Majelis Syuro' (legislatif) berisi tokoh-tokoh kaum Anshar dan Muhajirin. Kemudian, pada masa khalifah kedua, yaitu Umar Bin Khattab pembagian kekuasaan antara eksekutif, legislatif, dan yudikatif diperinci lewat undang-undang. Pada masa ini juga, Umar Bin Khattab membuat suatu undang-undang yang memisahkan antara kekuasaan eksekutif dengan yudikatif, dengan tujuan para qadhi sebagai pemegang kekuasaan yudikatif dalam memutuskan perkara harus bebas dari pengaruh eksekutif.

\section{Kekuasaan Legislatif}

Dalam kajian fiqh siyasah, legislasi atau kekuasaan legislatif disebut juga dengan majlis syuro ataupun alsulthah al-tasyri'iyah, yaitu kekuasaan pemerintah Islam dalam membuat dan menetapkan hukum.

Kekuasaan legislatif dalam teori Islam dipandang sebagai lembaga tertinggi dalam negara. Di samping diwajibkan memilih kepala negara, legislatif juga menempatkan undang-undang dan ketetapan yang dikeluarkan oleh lembaga legislatif ini akan dilandaskan secara efektif oleh lembaga eksekutif dan akan diperintahkan oleh lembaga eksekutif dan akan dipertahankan oleh lembaga yudikatif atau peradilan. ${ }^{31}$

Menurut Islam, tidak seorang pun berhak menetapkan suatu hukum yang akan diberlakukan bagi umat Islam. Hal ini ditegaskan sendiri oleh Allah dalam Surat al-An’am/6: 57:

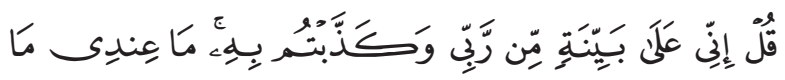

${ }^{31}$ Abul A'la Al-Maududi, Hukum dan Kontstitusi: sistem politik Islam, Tetj. Drs. Asep Hikmat, Mizan, Bandung, 1990, h 245 


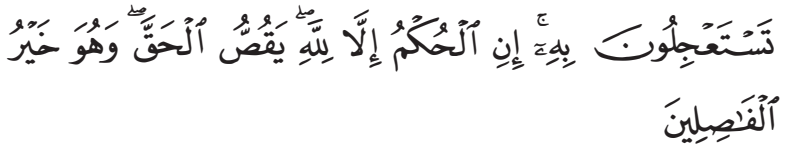

"Katakanlah: "Sesungguhnya aku berada di atas hujjah yang nyata (Alquran) dari Tuhanku, sedang kamu mendustakannya. Tidak ada padaku apa (azab) yang kamu minta supaya disegerakan kedatangannya. Menetapkan hukum itu hanyalah hak Allah. Dia menerangkan yang sebenarnya dan Dia Pemberi keputusan yang paling baik".

Akan tetapi, dalam wacana fiqh siyasah, istilah majlis syura atau al-sulthah al-tasyri'iyah digunakan untuk menunjukkan salah satu kewenangan atau kekuasaan pemerintah Islam dalam mengatur masalah kenegaraan, di samping kekuasaan eksekutif (al-sulthah al-tanfidziyah) dan kekuasaan yudikatif (al-sulthah al-qadha'iyah). Dalam konteks ini, kekuasaan legislatif (al-sulthah al-tasyri'iyah) berarti kekuasaan atau kewenangan pemerintah Islam untuk menetapkan hukum yang akan diberlakukan dan dilaksanakan oleh masyarakatnya berdasarkan ketentuan yang telah diturunkan Allah SWT. dalam syari'at Islam. ${ }^{32}$ Dengan demikian, unsur-unsur legislasi dalam Islam meliputi: ${ }^{33}$

1) Pemerintah sebagai pemegang kekuasaan untuk menetapkan hukum yang akan diberlakukan dalam masyarakat Islam;

2) Masyarakat Islam yang akan melaksanakannya;

3) Isi peraturan atau hukum itu sendiri yang harus sesuai dengan nilai-nilai dasar syari'at Islam.

Menurut Sayyid Abul A'la Maududi bahwa lembaga legislatif dalam suatu Negara Islam memiliki sejumlah fungsi yang harus dilakukannya:34

a. Jika terdapat pedoman-pedoman yang jelas dari Tuhan dan Rasulullah saw, meskipun legislatif tidak dapat mengubah atau menggantinya, maka hanya legislatif yang akan kompeten untuk menegakkannya dalam susunan dan bentuk pasal demi pasal, menggunakan definisi-definisi yang relevan dan rincian-rinciannya, serta menciptakan peraturan-peraturan dan undangundang untuk mengundangkannya;

\footnotetext{
${ }^{32}$ Muhammad Iqbal, Fiqh Siyasah .....h. 161.

${ }^{33}$ Ibid, h 162.

${ }^{34}$ Abul A'la Maududi, The Islamic Law......, h 245-246
}

b. Jika pedoman-pedoman Alquran dan Sunnah mempunyai kemungkinan interpretasi lebih dari satu, maka legislatiflah yang berhak memutuskan penafsiran mana yang harus ditempatkan dalam Kitab Undang-Undang Dasar. Untuk tujuan ini tidak ada tawar menawar lagi bahwa lembaga legislatif ini harus beranggotakan kumpulan orangorang terpelajar yang memiliki kemampuan dan kapasitas untuk menafsirkan perintah-perintah Alquran dan yang dalam memberikan berbagai keputusan tidak akan melepaskan diri dari jiwa atau isi Syari'ah. Pada dasarnya, harus diakui bahwa untuk tujuan perundang-undangan, suatu lembaga legislatif harus memiliki kewenangan untuk memberikan fatwa mengenai penafsiran mana yang harus lebih dipilih dan untuk menegakkan penafsiran yang lebih dipilihnya ini sebagai hukum, kecuali bahwa penafsiran itu hanya satu dan bukan merupakan pelanggaran atau penyimpangan semu dari hukum;

c. Jika tidak ada isyarat yang jelas dalam Alquran dan Sunnah, fungsi lembaga legislatif ini adalah untuk menegakkan hukum-hukum yang berkaitan dengan masalah yang sama, tentunya dengan selalu menjaga jiwa hukum Islam. Jika sudah ada hukum-hukum dalam bidang yang sama yang telah tercantum dalam kitab-kitab fiqh, maka dia bertugas untuk menganut salah satu di antaranya;

d. Jika Alquran dan Sunnah tidak memberikan pedoman yang sifatnya dasar sekalipun, atau masalah ini juga tidak ada dalam konvensi Khulafaurrasyidin, maka harus mengartikan bahwa Tuhan telah memberi kebebasan melakukan legislasi mengenai masalah ini menurut apa yang terbaik. Oleh karenanya, dalam kasus semacam ini, lembaga legislatif dapat merumuskan hukum tanpa batasan, sepanjang tidak bertentangan dengan jiwa dan semangat syari'ah.

Jadi, dengan kata lain, dalam majlis syura pemerintah melakukan tugas siyasah syar'iyahnya untuk membentuk suatu hukum yang akan diberlakukan di dalam masyarakat Islam demi kemaslahatan umat Islam, sesuai dengan semangat ajaran Islam. 


\section{2) Eksekutif}

Kekuasaan eksekutif dalam islam di sebut alsulthah al-tanfidziyah yang bertugas melaksanakan undang-undang. Di sini negara memiliki kewenangan untuk menjabarkan dan mengaktualisasikan perundang-undangan yang telah dirumuskan tersebut. Dalam hal ini, negara melakukan kebijaksanaan baik yang berhubungan dengan dalam negeri, maupun yang menyangkut dengan hubungan sesama negara (hubungan internasional).

Pelaksana tertinggi kekuasaan ini adalah pemerintah (kepala negara) dibantu oleh para pembantunya (kabinet atau dewan menteri) yang dibentuk sesuai dengan kebutuhan dan tuntutan situasi yang berbeda antara satu negara dengan negara Islam lainnya. Sebagaimana halnya kebijaksanaan legislatif yang tidak boleh menyimpang dari semangat nilai-nilai ajaran Islam, kebijaksanaan politik kekuasaan eksekutif juga harus sesuai dengan semangat nash dan kemaslahatan. ${ }^{35}$

Kepala negara dan pemerintah diadakan sebagai pengganti fungsi kenabian dalam menjaga agama dan mengatur dunia. Pengangkatan kepala negara untuk memimpin umat wajib menurut ijma. Jika kepemimpinan negara ini kewajiban, maka kewajiban itu gugur atas orang lain, jika tidak ada seorang pun yang menjabatnya maka kewajiban ini dibebankan kepada dua kelompok manusia. Pertama adalah orang-orang yang mempunyai wewenang memilih kepala negara bagi umat islam, kedua adalah orang-orang yang mempunyai kompetensi untuk memimpin negara sehingga mereka menunjuk salah seorang dari mereka yang memangku jabatan itu. ${ }^{36}$

Kewajiban-kewajiban yang harus diemban kepala negara itu meliputi semua kewajiban umum baik yang berkenaan dengan tugas-tugas keagamaan maupun kemasyarakatan, yang terdapat dalam Alquran dan sunnah Rasullullah seperti mempertahankan agama, menegakkan keadilan atau menyelesaikan perselisihan pihak yang bersengketa melalui penerapan hukum, mencegah kerusuhan

\footnotetext{
${ }^{35}$ Muhamad iqbal, fiqh siyasah......, h 137

${ }^{36}$ Imam al-mawardi, hukum tata negara dan kepemimpinan dalam sejarah islam, (jakarta; gema insani, 2000). h 16-17
}

dan melindungi hak-hak rakyat, melaksanakan amar ma'ruf nahi mungkar dan jihad, mengatur perokonomian negara dan membagi rampasan perang, dan sebagainya. Kewajiban utama dari seorang imam adalah mempraktikan totalitas syari'ah didalam umat dan menegakkan institusi-institusi yang menyerukan kebajiakan dan mencegah kejahatan.

Disamping itu, wewenang imam atau kepala negara adalah:

a) Menegakkan hukum dan bertindak juga sebagai juru bicara bagi masyarakat di luar wilayahnya.

b) Imam menegakkan hukum yang mengatur hubungan antara umat baik pada masa perang maupun masa perdamaian.

c) Mengeluarkan perintah perang

d) Memberlakukan hukum di wilayah-wilayah yang baru diduduki

e) Menghukum umat islam dan nono islam dalam wilayahnya apabila mereka terbukti melanggar hukum

f) Memutuskan kapan jihad dilakukan atau kapan jihad harus dihentikan

g) Menyarankan kapan umat Islam menerima dan menyetujui perdamaian.

Semua kewenangan ini bukan tanpa ada pembatasannya. Imam harus menjalankannya dalam batas-batas hukum tertentu, dengan memenuhi sasaran dan tujuan hukum dengan pihak musuh.

\section{3) Yudikatif}

Dalam kamus ilmu politik, yudikatif adalah kekuasaan yang mempunyai hubungan dengan tugas dan wewenang peradilan. Dan dalam konsep Fiqh Siyasah, kekuasaan yudikatif ini biasa disebut sebagai Sulthah Qadhaiyyah.

Tugas lembaga yudikatif adalah memutuskan perselisihan yang dilaporkan kepadanya dari orangorang yang berseteru dan menerapkan perundangundangan kepadanya dalam rangka menegakkan keadilan di muka bumi dan menetapkan kebenaran diantara orang-orang yang meminta peradilan. Pentingnya kekuasaan kehakiman adalah untuk menyelesaikan perkara-perkara perbantahan dan pemusuhan, pidana dan penganiyaan, melindungi 
masyarakat dan mengawasi harta wakaf dan lainlain pesoalan yang disampaikan kepada pengadilan. ${ }^{37}$

Penerapan syariat Islam bertujuan untuk menciptakan kemaslahatan. Dalam penerapannya (syariat Islam) memerlukan lembaga untuk penegakannya. Karena tanpa lembaga (alQadha) tersebut, hukum-hukum itu tidak dapat diterapkan. Dalam sistem pemerintah Islam, kewenangan peradilan (al-Qadha) terbagi ke dalam tiga wilayah, yaitu Wilayah Qadha, Wilayah Mazhalim, dan Wilayah Hisbah. ${ }^{38}$

Pada masa awal kekuasaan Islam, kekuasaan peradilan masih dipegang oleh Rasulullah saw. Beliau sendiri yang melaksanakan fungsi sebagai hakim atas berbagai persoalan dan sebagai pemimpin umat. Setelah Islam mulai berkembang dan kekuasaan Islam makin melebar, Rasulullah mulai mengangkat sahabat-sahabatnya untuk menjalankan kekuasaan di bidang peradilan di berbagai tempat. ${ }^{39}$ Rasulullah saw sendiri melaksanakan peranannya sebagai hakim setelah menerima firman Allah Swt yang memerintahkan kepada beliau untuk menyelesaikan persengketaan yang timbul, yaitu surat An Nisa' ayat 65;

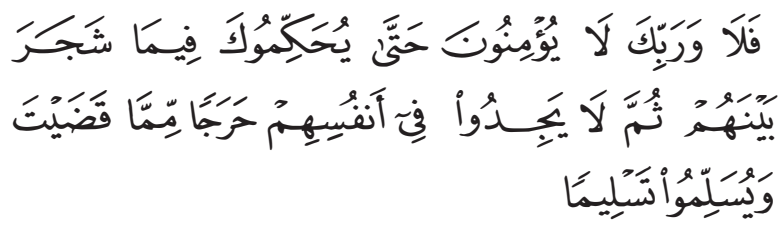

"Maka demi Tuhanmu, mereka (pada hakekatnya) tidak beriman hingga mereka menjadikan kamu hakim terhadap perkara yang mereka perselisihkan, kemudian mereka tidak merasa dalam hati mereka sesuatu keberatan terhadap putusan yang kamu berikan, dan mereka menerima dengan sepenuhnya"

Menurut Athiyah Musthafa Musyrifah, sebagaimana yang dikutip oleh Asadulloh Al Faruq, ciri khas peradilan pada masa Rasulullah saw setidaknya ada lima yaitu; 40

${ }^{37}$ Abul A'la Al-Maududi, Hukum Dan Konstitusi : Sistem Politik Islam, Penerjemah Asep Hikmat, Bandung: Mizan, 1993, h 247

${ }^{38}$ https://perbandinganmadzhabfiqh.wordpress.com/2011/05/14/ kekuasaan-yudikatif-sulthah-qadhaiyyah-konsep-wilayah-al-qadhawilayah-al-mazhalim-dan-wilayah-al-hisbah/, diakses pada selasa 18 juli 2017 pukul 17-00

${ }^{39}$ Asadulloh Al Faruq, Hukum Acara Peradilan Islam, h 4

${ }^{40}$ Asadulloh Al Faruq, Hukum Acara Peradilan Islam., h 5 a) Tidak ada pemisahan kekuasaan di bidang peradilan dengan kekuasaan di bidang lain, ini disimpulkan dari perkataan Ali, "kalau kamu telah menerima (keputusan itu) maka laksanakanlah, tetapi kalau kamu tidak mau menerimanya, maka aku cegah sebagian kamu dari sebagian yang lain (berbuat sesuatu), dan seterusnya";

b) Kekuasaan di bidang peradilan menyatu dengan kekuasaan di bidang fatwa;

c) Hakim memiliki kemerdekaan dalam menetapkan hukum atas perkara-perkara yang dihadapkan kepadanya.

d) Rasulullah saw mendelegasikan kekuasaan di bidang peradilan kepada sahabat yang memiliki kemampuan secara cepat, tepat dan memiliki kejujuran untuk menyelesaikan persoalan yang dihadapkan kepadanya;

e) Belum terdapat lembaga pemasyarakatan (penjara) sebagaimana yang dikenal di masa sekarang.

Di masa pemerintahan Khalifah Umar bin Khattab, terjadi perkembangan baru di bidang peradilan. Khalifah Umar memisahkan antara kekuasaan peradilan (yudikatif) dengan kekuasaan pemerintahan (eksekutif), beliau juga membatasi wewenang mereka dalam perkara-perkara perdata saja, perkara-perkara pidana dipegang sendiri oleh khalifah, atau oleh penguasa daerah. Para khalifah senantiasa mengawasi perbuatan para penguasa daerah dan hakimnya. Serta terus-menerus memberikan petunjuk-petunjuk dan bimbinganbimbingan. ${ }^{41}$

\section{Penutup}

Dari serangkaian uraian di atas, terdapat banyak persamaan antara pembagian kekuasaan menurut trias politica dan pembagian kekuasaan dalam prespektif siyasah:

\section{Lembaga eksekutif}

Terdapat persamaan kewenangannya yang bersifat prinsipil di antara keduanya (Imam dan Presiden), antara lain:

${ }^{41}$ TM Hasbi Ash Shiddieqy, Peradilan dan Hukum Acara Islam, hal 16 
a. Keduanya sama-sama dalam membentuk Undang-Undang bersama lembaga legislatif.

b. Keduanya sama dalam menjalankan undangundang.

c. Keduanya sama dalam menegakkan keadilan.

d. Keduanya merupakan perwujudan pelaksanaan kepemimpinan dalam memimpin rakyatnya.

e. Secara konseptual, kedua lembaga ini mengimpelementasikan wakil dari rakyat atau sebagai juru bicara rakyat untuk ke Negara lain.

f. Keduanya sama yang seluruh waktunya digunakan untuk untuk mengurus dan menata kehidupan masyarakat.

g. Keduanya sama-sama dalam menegakkan hukum untuk hubungan antara umat Islam dan umat non Islam.

h. Keduanya sama dalam mengeluarkan surat perintah perang.

i. Keduanya sama dalam menjalankan tugas kenegaraan.

j. Keduanya sama, tidak bisa membubarkan majelis syura atau Dewan Perwakilan Rakyat(Indonesia).

k. Keduanya sama dalam mengangkat dan memberhentikan menteri- menteri.

1. Keduanya sama-sama dalam kewenangan Menyarankan kapan umat Islam menerima dan menyetujui perdamaian dengan pihak musuh.

m. Keduanya sama-sama dalam kewenangan memberi gelar dan tanda jasa.

\section{Lembaga Legislatif}

Terdapat beberapa persamaan antara lembaga legislatif (DPR) dan al-sultah al-tasyri'iyah (majelis syura) menurut fikih siyasah, antara lain:

a. Keduanya sama-sama merupakan lembaga perwakilan rakyat;

b. Keduanya sama dalam membentuk UndangUndang;

c. Keduanya sama dalam melakukan pengawasan terhadap lembaga eksekutif

d. Keduanya sama dalam melakukan pengawasan terhadap anggaran keuangan negara

\section{Lembaga Yudikatif}

Terdapat beberapa persamaan antara lembaga yudikatif menurut trias politica dan al-sultah qada’iyyah menurut siyasah, antara lain

a. Keduanya sama merupakan lembaga peradilan

b. Keduanya sama dalam menjalankan undangundang yang dibentuk oleh lembaga legislatif

c. Keduanya sama-sama terdapat pembagian tugas atau wilayah hukum dalam memutuskan perkara, dalam mahkamah agung di Indonesia terdapat peradilan umum, peradilan agama, peradilan militer, dan peradilan TUN. Sedangkan dalam al-qada terdapatwilayah qadha, wilayah mazhalim, dan wilayah hisbah

d. Keduanya sama dalam menjalankan tugas negara

e. Keduanya sama dalam menegakkan keadilan

Selain adanya persamaan, terdapat pula perbedaan yang bersifat prinsipil antara pembagian kekuasaan menurut trias politica dan pembagian kekuasaan menurut siyasah.

\section{Lembaga Eksekutif}

Terdapat beberapa perbedaan kewenangan yang dimiliki antara presiden dan Imam (siyasah dusturiyah), antara lain:

a. Kepala Negara dalam Islam tidak ada kewenangan dalam memillih dan mengangkat anggota Dewan Pertimbangan Agung seperti kewenangan Presiden.

b. Kepala Negara dalam Islam tidak ada kewenangan Membentuk Peraturan Pemerintah Pengganti Undang-undang.

c. Kepala Negara dalam Islam tidak ada kewenangan Menetapkan Peraturan Pemerintah Pengganti Undang-undang.

d. Kepala Negara dalam Islam tidak ada kewenangan Mengangkat duta dan konsul.

e. Kepala Negara dalam Islam tidak ada kewenangan Memberi grasi, amnesti, abolisi, dan rehabilitasi.

\section{Lembaga Legislatif}

Terdapat beberapa perbedaan antara lembaga legislatif dan al-sultah al-tasyri'iyah (siyasah dusturiyah), antara lain:

a. Majelis syura tidak berwenang dalam membuat hukum sendiri, mereka harus membuat peraturan sesuai dengan Alquran dan Hadis. Sedangkan DPR berhak membuat dan membentuk peraturan perundang-undangan. 
b. Tugas majelis syura harus sesuai dengan aturan menurut Alquran dan Hadis, mereka tidak boleh merubah ataupun membuat aturan yang tidak ada dalam Alquran dan Hadis.

\section{Lembaga Yudikatif}

Terdapat beberapa perbedaan antara lembaga yudikatif dan al-sultah qada'iyyah (siyasah dusturiyah), antara lain:

a. Dalam lembaga yudikatif terdapat lembaga peradilan yang bernama mahkamah konstitusi, sedangkan dalam al-sultah qada'iyah tidak terdapat lembaga tersebut.

b. Lembaga yudikatif berwenang dalam melakukan uji peraturan undang-undang terhadap peraturan undang-undang yang lebih tinggi, sedangkan al-sultah qada'iyah tidak memiliki kewenangan tersebut.

\section{Pustaka acuan}

A.Djazuli, Fiqh Siyasah, Implementasi Kemaslahatan Umat dalam Rambu-Rambu Syari'ah, Jakarta: Prenada Media, 2003

Abul A'la Al-Maududi, Hukum dan Kontstitusi: sistem politik Islam, Tetj. Drs. Asep Hikmat, Mizan, Bandung, 1990

Al-Faruq, Asadullah. Hukum Acara Peradilan Islam. Yogyakarta: Pustaka Yustisia. 2009.

Al-Mawardi, Imam, Hukum Tata Negara Dan Kepemimpinan Dalam Sejarah Islam, Jakarta; Gema Insani, 2000

Arifin Firmansyah, Dkk, Lembaga Negara Dan Sengketa Lembaga Negara. Cet. 1. Jakarta: Konsorsium Reformasi Hukum Nasional (KRHAN), 2005

Asshiddiqie, Jimly, Pengantar Ilmu Hukum Tata Negara. Cetakan Kedua, PT Rajagrafindo Persada, Jakarta. 2010

Asshiddiqie, Jimly, Perkembangan Dan Konsulidasi Lembaga Negara Pasca Reformasi. Sinar Grafika, Jakarta, 2010

Asshiddiqie, Jimly, Pokok-Pokok Hukum Tata Negara Indonesia Pasca Reformasi, PT. Buana Indah Populer, Jakarta, 2008

Asshiddiqie, Jimly, Sejarah Terbentuknya DPR,
Jakarta, Darma Pustaka, 2011

Budiardjo, Miriam, Dasar-Dasar Ilmu Politik. Rev. ed, Cetakan Pertama, Gramedia, Jakarta, 2008

E.Utrech, Pengantar Hukum Administrasiu Negara Indonesia, Cet. 4, 1960

Gunawan A Tahuda, Komisi Negara Independen, Genta Press, Yogyakarta, 2012

Iqbal, Muhammad, Fiqh Siyasah, Kontektualisasi Doktrin Politik Islam, Jakarta, Gaya Media Pratama, 2007

Kantraprawira, Rusadi, Sistem Politik Indonesia : Suatu Model Pengantar. Bandung; Sinar Baru, 1998

Kusnardi, Moh,R. Saragih. Susunan Pembagian Kekuasaan Menurut Sistem Undang-Undang Dasar 1945. Jakarta: PT Gramedia Pustaka Utama. 1994

Mahdi, Imam, Hukum Tata Negara Indonesia, Teras, Yogyakarta, 2011.

Mahmuzar, Sistem Pemerintahan Indonesia Menurut UUD 1945 Sebelum dan Sesudah Amandemen, cet. I, Bandung: Nusa Media, 2010

Manan, Bagir, DPR, DPD, dan MPR dalam UUD 1945 baru, FH-UII Press, Yogyakarta, 2003

Pulungan, Suyuti, Fiqh Siyasah; Ajaran Sejrah Dan Pemikiran, Jakarta, PT Raja Gravindo, 1994

Qodir Jailani, Abdul, Negara Ideal Menurut Konsepsi Islam, Surabaya, PT Bina Ilmu, 1995

Riri Nazriyah, MPR RI : Kajian Terhadap Produk Hukum Dan Prospek Di Masa Depan. UII Press, Yogyakarta. 2007

Rohaniah Yoyoh, Efriza, Pengantar Ilmu Politik Kajian Mendasar Ilmu Politik, Malang, Intrans Publising 2005

Sjadzali, Munawir, Islam dan Tata Negara, Ajaran, Sejarah dan Pemikiran, Penerbit Universitas Indonesia, 1990

Syafi'i Ma'arif, Ahmad, Studi tentang Peraturan dan Konstituante Islam dan Masalah Kenegaraan, Jakarta, LP3ES, 1985

TM Hasbi Ash Shiddieqy, Peradilan dan Hukum Acara Islam, Semarang; Pustaka Rizki Putra, 2001

Yusuf al-Qardawi, Fiqh Daulah dalam Perspektif Al-Qur'an dan Sunnah, Alih Bahasa, Suhardi, Jakarta, Raja Grafindo, 1994 